\title{
Desain Pembelajaran Matematika Berbasis Hypothetical Learning Trajectory (HLT) Pada Materi Operasi Bilangan Bulat Siswa Kelas VII SMP Bunda Kasih Sudiang
}

\author{
Christian Moanoang $^{1, \text { a) }}$, Nurdin Arsyad ${ }^{1, \text { b) }}$, dan Nasrullah ${ }^{1}$ \\ ${ }^{1}$ Jurusan Matematika FMIPA Universitas Negeri Makassar \\ a)masjohn07@gmail.com \\ b)nurdin_arsyad@yahoo.com
}

\begin{abstract}
Abstrak. Penelitian ini bertujuan untuk menghasilkan suatu desain pembelajaran berbasis Hypotetical Learning Trajectory (HLT) pada materi operasi bilangan yang dapat membuat siswa kelas VII memahami materi operasi bilangan bulat dan menyelesaikan masalah yang berkaitan dengan operasi bilangan bulat. Jenis penelitian yang digunakan adalah Design Research. Subjek penelitian ini adalah siswa kelas VII. Pada penelitian ini, peneliti membuat HLT sebagai dugaan awal dari aktivitas pembelajaran yang dilakukan dalam dua siklus uji coba hingga didapatkan desain pembelajaran yang diharapkan. Hasil analisis retrospektif menunjukkan desain pembelajaran yang disusun memberikan perubahan positif terhadap siswa kelas VII dalam memahami konsep operasi bilangan bulat. Dari hasil kerja beberapa kelompok diperoleh bahwa sebagian besar siswa telah mencapai tujuan pembelajaran yaitu memahami bilangan bulat, menentukan hasil penjumlahan bilangan bulat, menentukan hasil pengurangan bilangan bulat serta menyelesaikan masalah sehari-hari berkaitan dengan operasi bilangan bulat. Hasil kerja tersebut disertai dengan dugaan-dugan yang terjadi maupun tidak terjadi dalam proses pembelajaran pada (HLT).
\end{abstract}

Kata Kunci: Design Research, Dugaan Lintasan Belajar, Operasi Bilangan Bulat.

\begin{abstract}
This research aims to produce a design-based Hypothetical Learning Trajectory (HLT) learning in the integer's operations materials that can make class VII students understand the integer's operations materials and resolve issues related to integer's operations. The type of research used is Design Research. The subject of this study was a grade VII junior high students. In this research, researchers made HLT the earliest suspect of the learning activity carried out in two test cycles until the expected learning design was obtained. The results of a retrospective analysis showed that the design of learning was compiled to provide positive changes to class VII junior high students in understanding the concept of integer's operations. From the work of several groups, the majority of students have achieved the learning objectives, namely understanding integers, determining the sum of integers, determining the reduction of integers and solve daily problems relating to integer's operations. The work of students are accompanied by conjectures that occur or do not occur in the learning process that has been compiled in HLT.
\end{abstract}

Keywords: Design Research, Hypothetical Learning Trajectory, Integer's Operation

\section{PENDAHULUAN}

Matematika merupakan pengetahuan yang objeknya ada yang bersifat abstrak, berdasar pada kebenaran yang konsisten dan tersusun berdasarkan konsep hirarkis. Matematika merupakan ilmu pengetahuan yang diajarkan pada setiap jenjang persekolahan. Pada pembelajaran matematika di sekolah, salah satu materi yang memiliki kendala untuk diajarkan pada siswa 
kelas VII adalah operasi bilangan bulat khususnya yang melibatkan bilangan negatif. Blair, Rosenberg-Lee, Tsang, Schwartz, dan Menon (2012) menyatakan bahwa bilangan negatif tidak memiliki persepsi yang jelas, dan karena itu, para siswa harus berusaha lebih keras dalam belajar bilangan negatif.

Hasil tes awal operasi bilangan bulat kepada 15 siswa kelas VII SMP hanya satu orang yang dapat menjawab setiap soal dengan benar. Salah satu soal diantara delapan butir soal yang diberikan yaitu " $-9-(-5)=\cdots "$. Adapun jawaban yang diberikan siswa terhadap soal tersebut sangat beragam, misalnya " $-9-(-5)=45 "$. Dugaan siswa memberi jawaban tersebut dapat dikarenakan siswa masih terpengaruh dengan konsep perkalian dua bilangan bertanda negatif (Pemu dan Rahman, 2018). Hal tersebut berarti kesalahan siswa disebabkan siswa yang masih belum paham dengan konsep pengurangan dalam operasi bilangan bulat yang melibatkan bilangan negatif.

Hal tersebut menuntut guru agar memiliki kemampuan dalam menanamkan konsep yang baik kepada siswa sehingga mereka tidak lagi memiliki pemahaman konsep yang keliru terhadap materi operasi bilangan bulat. Salah satu cara yang dapat dilakukan guru adalah menduga lintasan belajar yang akan dialami oleh siswa. Menurut Nurdin (2011) alur belajar memberikan petunjuk bagi guru dalam menentukan tujuan pembelajaran yang akan dicapai oleh siswa dan untuk mencapai tujuan pembelajaran tersebut guru membuat langkah-langkah pembelajaran yang disusun berdasarkan pengetahuan awal mengenai siswa.

Dugaan-dugaan yang diperoleh dapat dijadikan acuan dalam merancang pembelajaran yang sesuai diterapkan untuk mengatasi masalah yang dialami siswa ketika mempelajari materi operasi bilangan bulat. Rancangan pembelajaran dalam kelas yang bertujuan untuk membuat siswa memahami suatu materi dapat disebut sebagai desain pembelajaran. Desain pembelajaran tersebut berperan sebagai panduan guru dalam melakukan proses pembelajaran yang didasarkan pada dugaan-dugaan yang diperoleh.

Simon (1995) mengenalkan suatu HLT atau dugaan lintasan belajar yang disediakan oleh guru pada pemikiran untuk memilih desain pembelajaran khusus sehingga tujuan untuk membuat seluruh siswa paham terhadap materi yang diajarkan oleh guru. Menurut Simon (1995) pengembangan HLT diformulasikan dalam tiga komponen yaitu : tujuan pembelajaran, instrumen pembelajaran yang akan digunakan dan hypothetical learning proses yang mengantisipasi bagaimana proses berfikir kritis dan kreatif siswa dapat dikembangkan.

Beberapa penelitian yang telah dilakukan berkaitan dengan HLT (Wijaya, 2009; Putri, 2012; Rahmadanti, Siahaan, dan Fathurohman, 2015; Wijaya, 2015; Eswindha \& Puspandari, 2016). Eswindha \& Puspandari (2016) meneliti tentang pembelajaran konsep perkalian melalui HLT dengan meronce karet yeye. Hasil dari penelitian tersebut desain pembelajaran HLT dengan media karet yeye dapat merangsang siswa untuk membangun konsep perkalian. Wijaya (2015) meneliti tentang pengembangan beragam kemampuan siswa melalui HLT sebagai instrumen pembelajaran. Hasil dari penelitian tersebut adalah kemampuan siswa berkembang secara umum dalam kategori baik serta aktivitas siswa berapa pada kategori baik.

Hasil dari penelitian ini adalah desain pembelajaran matematika berbasis HLT dan dugaan yang termuat pada desain pembelajaran tersebut membantu guru dalam menentukan tindakan untuk proses pembelajaran selanjutnya. Dugaan lintasan belajar atau HLT dapat digunakan sebagai pedoman pelaksanaan pembelajaran di kelas sekaligus tindakan pencegahan terhadap kemungkinan masalah yang dihadapi oleh siswa dalam proses pembelajaran. Dugaan dalam HLT berkaitan dengan bagaimana kemampuan berpikir dan pemahaman siswa akan berkembang dalam aktivitas belajar yang dirancang oleh guru. 
Dari uraian tersebut, penulis telah melakukan penelitian yang berjudul:"Desain Pembelajaran Matematika Berbasis Hypothetical Learning Trajectory (HLT) pada Materi Operasi Bilangan Bulat Siswa Kelas VII SMP Bunda Kasih Sudiang”.

\section{METODE PENELITIAN}

Jenis penelitian yang digunakan adalah penelitian rancangan (Design Research). Subjek pada penelitian ini adalah 16 orang siswa SMP kelas VII yang kemudian dikelompokkan menjadi dua kelompok, 8 orang siswa pada siklus Pilot Experiment dan 8 orang siswa pada siklus Teaching Experiment.

Instrumen penelitian yang digunakan adalah lembar observasi aktivitas siswa serta wawancara semiterstruktur yang sebelumnya divalidasi oleh dua orang ahli. Adapun perangkat pembelajaran yang digunakan adalah desain HLT, Rencana Pelaksanaan Pembelajaran (RPP), dan Lembar Kerja Peserta Didik (LKPD). Data yang terkumpul berupa hasil kerja peseta didik, hasil observasi aktivitas siswa, serta transkrip wawancara yang dianalisis dengan analisis retrospektif untuk menemukan kesimpulan desain pembelajaran berdasarkan desain yang diperoleh.

\section{HASIL DAN PEMBAHASAN}

Penelitian ini bertujuan untuk menghasilkan suatu desain pembelajaran matematika berbasis HLT yang dapat membuat siswa kelas VII memahami materi operasi bilangan bulat dan menyelesaikan masalah yang berkaitan dengan operasi bilangan bulat. Untuk mencapai tujuan tersebut, penelitian ini menggunakan metode penelitian Design Reseacrh pada siswa kelas VII SMP pada tahun ajaran 2019/2020.

\section{Siklus Pilot Experiment}

\section{Tahap 1: Desain Pendahuluan}

Pada tahap desain pendahuluan, peneliti memulainya dengan mengklasifikasikan tujuan-tujuan pembelajaran yang akan dicapai oleh siswa pada saat pembelajaran dilakukan yang bersumber pada silabus pembelajaran matematika untuk SMP/MTs kurikulum 2013 untuk kelas VII. Selanjutnya dari tujuan pembelajaran tersebut peneliti menentukan aktivitas-aktivitas lintasan belajar yang termuat pada Rencana Pelaksanaan Pembelajaran (RPP). Kemudian peneliti mendesain Lembar Kerja Peserta Didik (LKPD) yang akan digunakan dalam proses pembelajaran.

\section{Tahap 2: Uji Coba Desain}

Uji coba desain pada tahap ini dilakukan pada 8 orang siswa kelas VII. Uji coba ini dilakukan untuk menguji desain awal HLT. Selama uji coba dilaksanakan, serangkaian aktivitas dilaksanakan sesuai dengan yang termuat pada LKPD. Uji coba desain pada siklus ini dilakukan dalam dua pertemuan. Pertemuan pertama dengan alokasi waktu 2 x 40 menit dan pertemuan kedua dengan alokasi waktu 3 x 40 menit. Pada pertemuan pertama siswa melakukan aktivitas pada LKPD 1 dan pada peremuan kedua siswa melakukan aktivitas pada LKPD 2. Aktivitas 
pada masing-masing LKPD tersebut dikerjakan secara berkelompok yang terdiri dari 2 orang siswa.

\section{Tahap 3: Analisis Retrospektif}

Setelah desain diuji coba dalam proses pembelajaran, data yang diperoleh pada saat melaksanakan uji coba dikumpulkan kemudian dianalisis secara retrospektif. Analisis retrospektif dilakukan untuk mengeavluasi dugaan-dugaan yang terjadi maupun yang tidak terjadi pada desain awal HLT.

Berikut Tabel 1 merupakan perbandingan antara HLT yang telah didesain dengan hasil Pilot Experiment.

TABEL 1. Perbandingan antara HLT yang telah didesain dengan hasil Pilot Experiment

\section{HLT}

Siswa menuliskan bilangan-bilangan yang termasuk bilangan bulat.

Siswa tidak menjawab soal yang Siswa tidak dapat menjawab soal nomor 2 menggunakan komutatif.

Siswa tidak dapat menentukan hasil pengurangan jika bilangan bertanda negatif dikurang bilangan positif.

Siswa tidak dapat menentukan hal yang diketahui.

\section{Hasil Pilot Experiment}

Siswa dapat menuliskan bilangan-bilangan bulat tetapi secara berurutan.

aktivitas 2-1 karena kebingungan dengan tanda operasi.

$(-6)+(-7)=(-7)+(-6)=-7-6=$ $-1$

Siswa keliru dalam melakukan pengurangan karena pemahaman konsep yang salah.

$(-6)-(-7)=(-6)+(-7)=-13$

Siswa tidak menuliskan hal-hal yang diketahui dari soal.

\section{Siklus Teaching Experiment}

\section{Tahap 1: Desain Pendahuluan}

TABEL 2. Perbaikan pada HLT

Hasil Pilot Experiment

\section{Perbaikan}

Siswa tidak dapat menjawab soal nomor 2 aktivitas 2-1 karena kebingungan dengan tanda operasi.

$$
\begin{aligned}
& (-6)+(-7)=(-7)+(-6)=-7-6= \\
& -1
\end{aligned}
$$

Tanda negatif ditambahkan dalam soal agar lebih memudahkan.

$$
(-6)+(-7)=(-\cdots)+(-\cdots)=\cdots
$$

Siswa keliru dalam melakukan pengurangan karena pemahaman konsep yang salah.

$$
(-6)-(-7)=(-6)+(-7)=-13
$$

Memperjelas perubahan tanda pada siswa agar tidak terjadi kesalahan dalam penulisan soal.

$$
(-6)-(-7)=(-6)+(\ldots)=\cdots
$$

Siswa tidak menuliskan hal-hal yang Mengarahkan siswa agar mengisi hal-hal diketahui dari soal. yang perlu dijawab dalam soal

Pada tahap desain pendahuluan, dilakukan perbaikan terhadap kekurangan yang ada pada siklus Pilot Experiment. LKPD juga diperbaiki sesuai dengan hasil dari analisis 
retrospektif untuk mengatasi kesalahan-kesalahan siswa pada siklus sebelumnya. Perbaikan-perbaikan dapat dilihat pada Tabel 2.

\section{Tahap 2: Uji Coba Desain}

Uji coba desain pada tahap ini dilakukan pada 8 orang siswa kelas VII. Uji coba ini dilakukan untuk menguji desain awal HLT. Selama uji coba dilaksanakan, serangkaian aktivitas dilaksanakan sesuai dengan yang termuat pada LKPD. Uji coba desain pada siklus ini dilakukan dalam dua pertemuan. Pertemuan pertama dengan alokasi waktu 2 × 40 menit dan pertemuan kedua dengan alokasi waktu 3 x 40 menit. Pada pertemuan pertama siswa melakukan aktivitas pada LKPD 1 dan pada peremuan kedua siswa melakukan aktivitas pada LKPD 2. Aktivitas pada masing-masing LKPD tersebut dikerjakan secara berkelompok yang terdiri dari 2 orang siswa.

\section{Tahap 3: Analisis Retrospektif}

Setelah desain diuji coba dalam proses pembelajaran, data yang diperoleh pada saat melaksanakan uji coba dikumpulkan kemudian dianalisis secara retrospektif. Analisis retrospektif dilakukan untuk mengeavluasi dugaan-dugaan yang terjadi maupun yang tidak terjadi pada desain awal HLT.

Berikut Tabel 1 merupakan perbandingan antara HLT yang telah didesain dengan hasil Pilot Experiment.

TABEL 3. Perbandingan antara HLT yang telah didesain dengan hasil Pilot Experiment

HLT Hasil Pilot Experiment

Siswa menuliskan bilangan-bilangan yang Siswa dapat menuliskan bilangan-bilangan termasuk bilangan bulat.

Siswa tidak menjawab soal yang Siswa tidak dapat menjawab soal nomor 2 menggunakan komutatif. aktivitas 2-1 karena kebingungan dengan tanda operasi.

$$
\begin{aligned}
& (-6)+(-7)=(-7)+(-6)=-7-6= \\
& -1
\end{aligned}
$$

Siswa tidak dapat menentukan hasil Siswa keliru dalam melakukan pengurangan pengurangan jika bilangan bertanda negatif karena pemahaman konsep yang salah. dikurang bilangan positif.

Siswa tidak dapat menentukan hal yang diketahui. $(-6)-(-7)=(-6)+(-7)=-13$

Siswa tidak menuliskan hal-hal yang diketahui dari soal.

\section{Pembahasan}

Pada Pilot Experiment, dugaan lintasan belajar I desain awal yang telah disusun, terdapat butir hipotesis 25 yang tidak terjadi, 29 butir yang terjadi, serta terdapat 5 butir dugaan tambahan berdasarkan pengamatan pada saat proses pembelajaran berlangsung. Sedangkan mengenai dugaan lintasan belajar II desain awal yang telah disusun, terdapat 20 butir hipotesis yang tidak terjadi, 26 butir yang terjadi, serta terdapat 4 butir dugaan tambahan berdasarkan pengamatan pada saat proses pembelajaran berlangsung. Adapun beberapa dugaan-dugaan yang terjadi pada Pilot Experiment adalah sebagai berikut:

1. Saat siswa diminta untuk menyebutkan dan menuliskan 10 bilangan yang termasuk bilangan bulat negatif serta positif, siswa menuliskan bilangan-bilangan tersebut secara 
berurutan. Siswa menuliskan secara berurutan dengan anggapan bahwa hal itu lebih mudah. Namun karena keterbatasan peneliti, peneliti belum dapat menemukan teori yang dapat mendukung pendapat peneliti tersebut.

2. Saat diberikan soal penjumlahan dua bilangan bulat negatif, siswa menjawab salah pada soal tersebut. Contohnya " $-9+(-2)=-7$ " “ $-7+(-6)=-1$ ". Dalam hal tersebut siswa melakukan kesalahan dalam melakukan penjumlahan dua bilangan negatif karena kesalahan dalam konsep yaitu mereka mengurangkan bilangan tersebut sehingga hasil yang diperoleh tidak tepat. Hal tersebut sejalan dengan pendapat Badriyah, As'ari, dan Susanto (2016) bahwa kesalahan tersebut termasuk dalam concept errors (CO) jika siswa melakukan kesalahan dalam melakukan penjumlahan.

3. Saat diberikan soal penjumlahan bilangan bulat puluhan, siswa tidak dapat menjawab soal dengan benar. Contohnya " $(-26+(-19))+(-18)=-25$ ”. Kesalahan pertama pada " $-26+(-19)$ " hasil yang diperoleh dari penjumlahan tersebut adalah -7 . Kesalahan tersebut merupakan kesalahan pada konsep penjumlahan dua bilangan bulat negatif. Kesalahan berikutnya adalah mereka mendapatkan hasil yang benar dari “ $-7+(-18)$ " mereka menjawab -25 . Mereka benar dalam melakukan perhitungan namun jawaban tersebut merupakan jawaban yang salah untuk keseluruhan soal. Hal tersebut sejalan dengan pendapat Badriyah, As'ari, dan Susanto (2016) yang menyatakan bahwa kekeliruan dalam menghitung penjumlahan dua bilangan negatif dapat disebabkan kekeliruan dalam memahami konsep dari operasi bilangan bulat.

4. Saat diberikan soal penjumlahan bilangan bulat satuan berbeda tanda, siswa tidak dapat menjawab soal yang terdapat operasi tambah bertemu tanda negatif. Contohnya " $9+$ $(-6)=-3$ ". Kesalahan tersebut timbul akibat adanya kesalahan dari siswa memaknai operasi tambah yang bertemu tanda negatif sehingga hasil yang diperoleh tidak tepat. Hal tersebut sejalan dengan pendapat dari Badriyah, As'ari, dan Susanto (2016) yang menyatakan bahwa kekeliruan dalam menghitung penjumlahan bilangan bulat dapat disebabkan kekeliruan dalam memahami konsep dari operasi bilangan bulat.

5. Saat diberikan soal menentukan hasil penjumlahan bilangan bulat puluhan berbeda tanda, siswa tidak dapat menjawab dengan benar soal menentukan hasil penjumlahan bilangan puluhan negatif dan positif. Contohnya $-23+42=21$. Dalam hal tersebut siswa salah dalam melakukan perhitungan pada operasi bilangan bulat puluhan tersebut. Hal tersebut sejalan dengan pendapat Badriyah, As'ari, dan Susanto (2016) yang menyatakan bahwa siswa dapat melakukan kesalahan perhitungan pada saat melakukan perhitungan suatu soal. Kesalahan tersebut menurut Badriyah, As'ari, dan Susanto (2016) dikatakan sebagai Careless Errors atau kurang ketelitian dalam melakukan perhitungan.

Pada Teaching Experiment, dugaan lintasan belajar I desain perbaikan yang telah disusun, terdapat butir hipotesis 4 yang tidak terjadi, 25 butir yang terjadi, serta tidak ada butir dugaan tambahan berdasarkan pengamatan pada saat proses pembelajaran berlangsung. Sedangkan mengenai dugaan lintasan belajar II desain perbaikan yang telah disusun, terdapat 6 butir hipotesis yang tidak terjadi, 22 butir yang terjadi, serta terdapat 1 butir dugaan tambahan berdasarkan pengamatan pada saat proses pembelajaran berlangsung. Adapun beberapa dugaan-dugaan yang terjadi pada Teaching Experiment adalah sebagai berikut:

1. Saat diberikan soal pengurangan dua bilangan bulat satuan sama tanda, siswa tidak dapat menjawab dengan benar soal tersebut. Contohnya, " $5-2=5+(-5)=0$ " dan " $2-6=2+(-2)=0$ ". Dalam hal tersebut siswa kurang teliti dalam menjawab soal karena kesalahan dalam merubah bentuk pengurangan tersebut. Hal tersebut sejalan dengan pendapat Badriyah, As'ari, dan Susanto (2016) yang mengatakan bahwa siswa dapat menjawab soal dengan kurang teliti sehingga hasil yang diperoleh tidak tepat. 
2. Saat diberikan soal pengurangan dua bilangan bulat puluhan sama tanda, siswa tidak dapat menjawab dengan benar soal tersebut. Contohnya, $25-58=25+(-58)=-7$. Dalam hal tersebut siswa sangat keliru dalam melakukan perhitungan karena hasil yang diperoleh sangat jauh dari hasil yang tepat. Kesalahan perhitungan tersebut dapat terjadi karena kecerobohan yang dilakukan oleh siswa tersebut dalam menghitung. Hal tersebut sejalan dengan pendapat Badriyah, As'ari, dan Susanto (2016) yang mengatakan bahwa siswa dapat menjawab soal dengan ceroboh dalam melakukan pengurangan bilangan bulat sama tanda dalam operasi bilangan bulat sehingga hasil yang diperoleh tidak tepat.

3. Saat diberikan soal pengurangan dua bilangan bulat satuan berbeda tanda, siswa tidak dapat menjawab soal pengurangan bilangan bulat negatif dengan bilangan positif dengan benar. Contohnya, " $-9-6=-16$ ". Dalam hal tersebut siswa ceroboh dalam melakukan perhitungan dan tergesa-gesa sehingga hasil yang diperoleh tidak tepat. Hal tersebut sejalan dengan pendapat Badriyah, As'ari, dan Susanto (2016) yang mengatakan bahwa siswa dapat melakukan kecerobohan saat perhitungan dalam operasi bilangan bulat sehingga hasil yang diperoleh tidak tepat.

4. Siswa diberikan soal pengurangan bilangan bulat puluhan berbeda tanda, siswa tidak dapat menentukan hasil pengurangan dua bilangan bulat puluhan berbeda tanda. Contohnya " $27-(-56)=27+56=85$ ". Kesalahan siswa pada soal tersebut adalah tidak berhati-hati dalam menjumlahkan bilangan-bilangan tersebut. Hasil yang seharusnya diperoleh adalah 83 tetapi karena kesalahan perhitungan karena kecerobohan maka hasil yang mereka peroleh 85 . Hal tersebut sejalan dengan pendapat Badriyah, As'ari, dan Susanto (2016) yang mengatakan bahwa kecerobohan siswa berperan dalam kesalahan siswa dalam menentukan hasil penjumlahan dua bilangan pada operasi bilangan bulat

5. Siswa diminta untuk menyelesaikan soal permasalahan sehari-hari yang berkaitan dengan operasi bilangan bulat, siswa tidak dapat menentukan hal yang ditanyakan. Kesalahan tersebut hadir akibat kurang teliti siswa dalam proses menjawab sehingga hasil tersebut kurang tepat. Hal tersebut sejalan dengan pendapat Badriyah, As'ari, dan Susanto (2016) yang menyatakan bahwa salah satu kesalahan yang dilakukan siswa pada saat mengerjakan soal operasi bilangan bulat adalah kurang teliti dalam menyelesaikan solusi.

Dari proses pembelajaran yang telah dilaksanakan, dapat diperoleh hasil bahwa sebagian besar siswa telah mampu mencapai tujuan pembelajaran lewat serangkaian aktivitas yang dilakukan pada LKPD 1 dan LKPD 2. Dari hasil pengamatan aktivitas siswa diperoleh bahwa siswa aktif dalam mengikuti serangkaian aktivitas yang telah didesain dalam proses pembelajaran. Selanjutnya dari hasil wawancara terhadap 8 perwakilan kelompok diperoleh bahwa setiap siswa dapat mengerjakan setiap aktivitas yang diberikan namun karena kecerobohan dan kekeliruan perhitungan baik penjumlahan dan pengurangan sehingga menyebabkan beberapa siswa melakukan kesalahan dalam menjawab soal-soal pada serangkaian aktivitas pada proses pembelajaran. Hasil tersebut menunjukkan bahwa desain pembelajaran matematika berbasis Hypothetical Learning Trajectory (HLT) yang dikembangkan dapat membantu siswa untuk lebih memahami materi operasi bilangan bulat. Berikut ini adalah HLT yang pada LKPD 1 (Gambar 2) dan LKPD 2 (Gambar 3) 


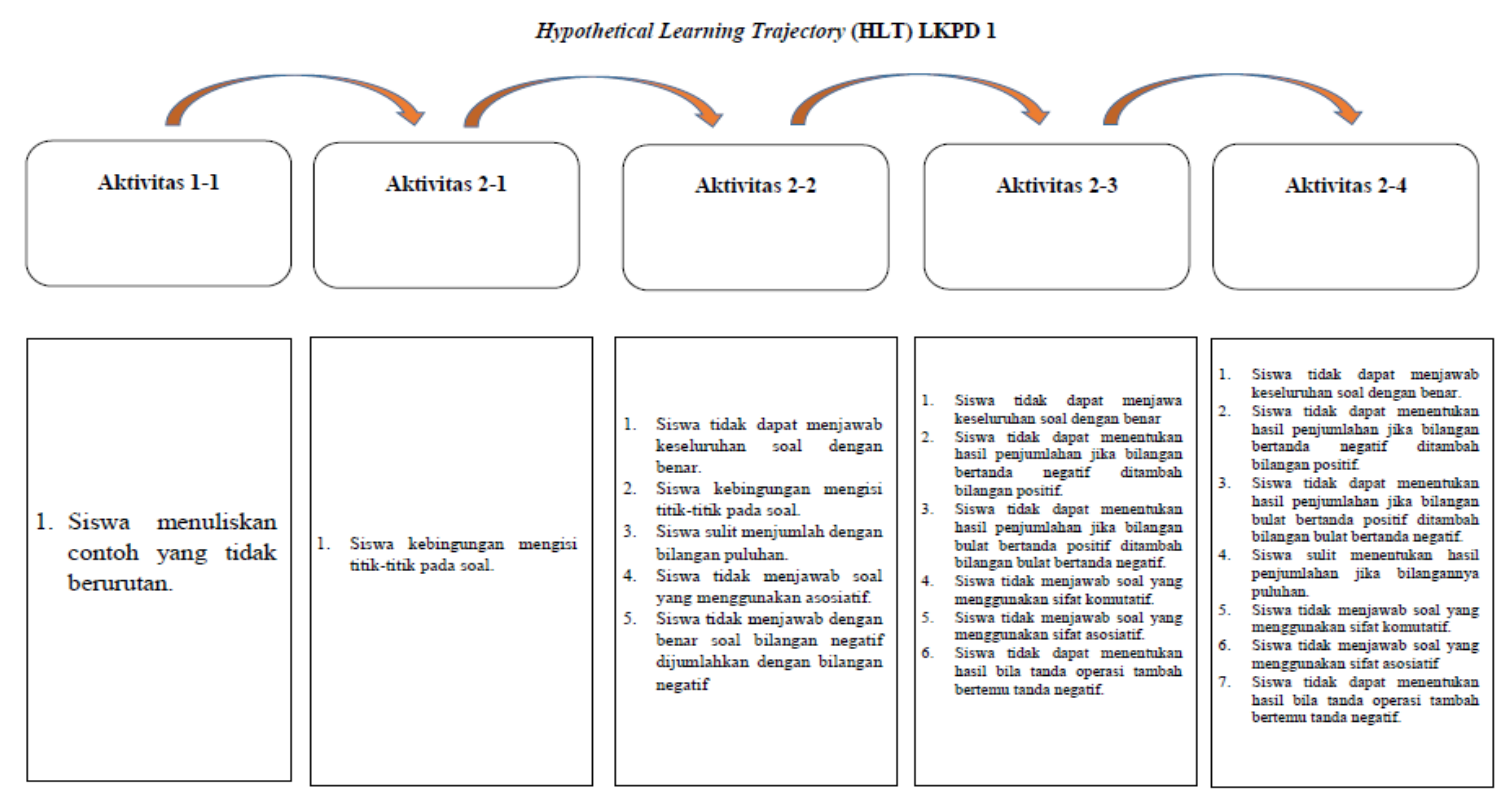

GAMBAR 2. HLT pada LKPD 1

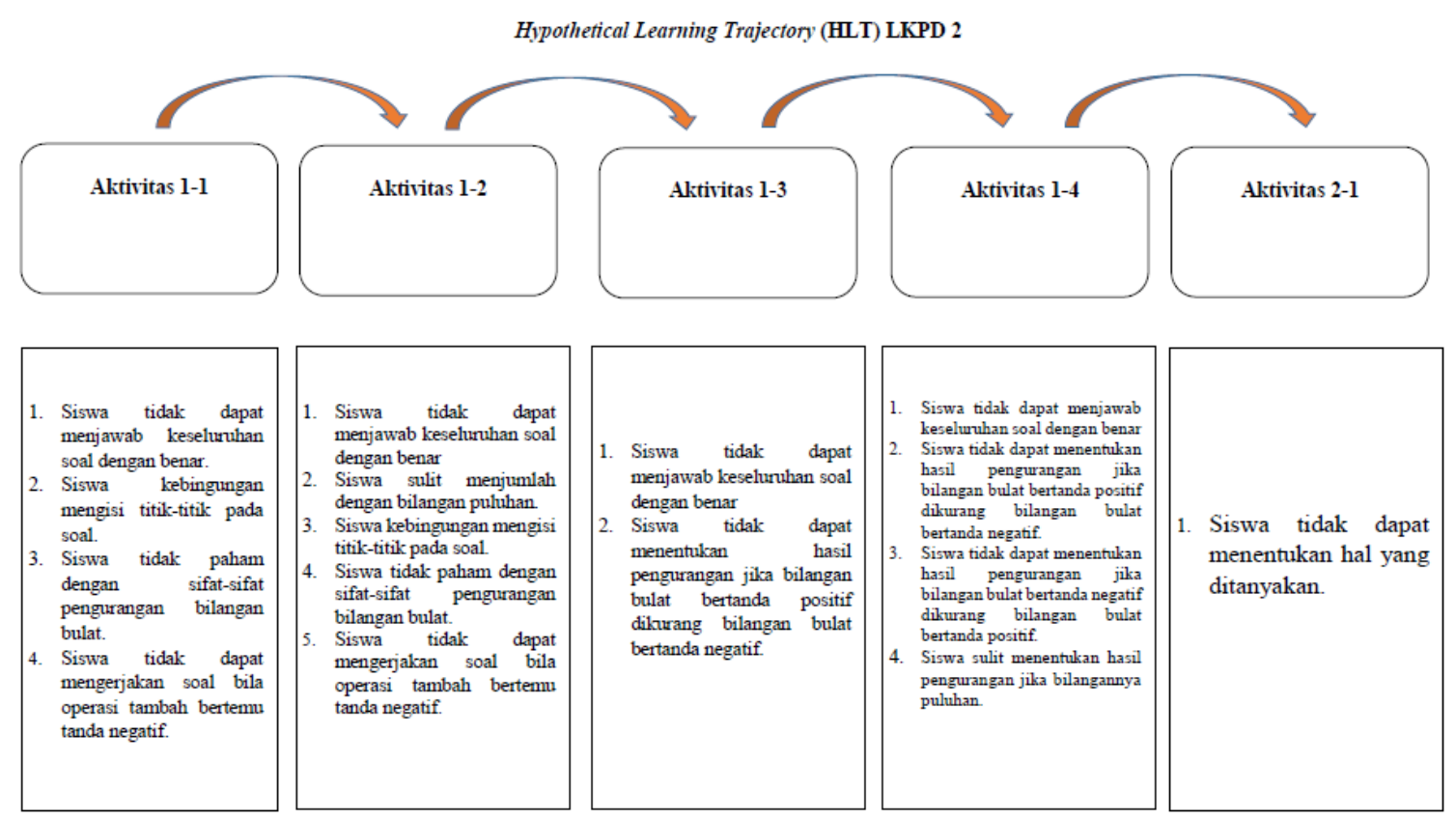

GAMBAR 3. HLT pada LKPD 2

\section{KESIMPULAN}

Berdasarkan hasil analisis retrospektif, hasil wawancara serta pengamatan terhadap proses pembelajaran, dihasilkan suatu desain pembelajaran matematika berbasis Hypothetical Learning Trajectory (HLT) pada materi operasi bilangan bulat siswa kelas VII SMP. Dalam desain pembelajaran tersebut memuat dugaan-dugaan yang terjadi pada saat proses pembelajaran. 


\section{DAFTAR PUSTAKA}

Badriyah, L., As'ari, A.R. \& Susanto, H.2016. Profil Kesalahan Siswa SMP Dalam Menyelesaikan Operasi Hitung Bilangan Bulat. Prosiding Seminar Nasional Matematika dan Pembelajarannya, (pp. 485-491). Malang, Indonesia: Universitas Negeri Malang.

Blair, K.P., Rosenberg-Lee, M., Tsang, J.M., Schwartz, D.L., \& Menon, V.2012. Beyond natural numbers: negative number representation in parietal cortex. Frontiers in Human Neuroscience, 6(7). 1-17.

Eswindha, B. \& Puspandari, E.K.2016.Pembelajaran Konsep Perkalian Melalui Hypothetical Learning Trajectory (HLT) dengan Meronce Karet Yeye. Prosiding Seminar Nasional Matematika dan Terapannya, (pp. 285-296). Purwokerto, Indonesia: Universitas Jendral Sudirman.

Nurdin.2011.Trajektori dalam Pembelajaran Matematika. Edumatica, 1(1). 2-7.

Pemu, N \& Rahman, A.2018.Penggunaan Tarser dalam Menyelesaikan Soal Operasi Penjumlahan dan Pengurangan pada Bilangan Bulat Tingkat SMP. Kreano: Jurnal Matematika Kreatif dan Inovatif, 9(2). 114-119.

Simon, M.A.1995. Reconstructing Mathematics Pedadogy From A Constructivist Perspective. Journal for Reasearch in Mathematics Education, 26(2). 114-145.

Putri, R.I.I.2012. Pendisainan Hypothetical Learning Trajectory (HLT) Cerita Malin Kundang pada Pembelajaran Matematika. Prosiding Seminar Nasional Matematika dan Pendidikan Matematika, (pp. 17-24). Yogyakarta, Indonesia: Universitas Negeri Yogyakarta.

Rahmadanti, P., Siahaan, S.M., \& Fathurohman, A.2015.Penggunaan Hypothetical Learning Trajectory (HLT) pada Materi Elastisitas Untuk Mengetahui Lintasan Belajar Siswa Kelas X di SMA Negeri 1 Indralaya Utara. Jurnal Inovasi dan Pembelajaran Fisika, 2(1). 88-99.

Wijaya, A.2009. Hypothetical Learning Trajectory dan Peningkatan Pemahaman Konsep Pengukuran Panjang. Prosiding Seminar Nasional Matematika dan Pendidikan Matematika, (pp. 373-387). Yogyakarta, Indonesia: Universitas Negeri Yogyakarta.

Wijaya, A.F.C.2015.Profil Kemampuan Analisis Respon Siswa melalui Hypothetical Learning Trajectory sebagai Instrumen Pembelajaran dalam Pengembangan Beragam Kemampuan Siswa. Prosiding Simposium Nasional Inovasi dan Pembelajaran Sains (pp. 185-188). Bandung, Indonesia: Institut Teknologi Bandung. 